\title{
Grain Amylose Content and its Stability over Seasons in a Selected Set of Rice Varieties Grown in Sri Lanka
}

\author{
W. K. S. M. Abeysekera ${ }^{1}$, G. A. S. Premakumara ${ }^{1}$, A. P. Bentota ${ }^{2}$ \\ and D. Sumith de Z. Abeysiriwardena ${ }^{3}$
}

Received: $24^{\text {th }}$ March $2016 /$ Accepted: $27^{\text {th }}$ September 2016

\begin{abstract}
Grain amylose content, one of the key parameters determining cooking and eating quality of rice, varies among varieties. Identification of varieties with different grain amylose contents that are stable over seasons is important to improve the quality of rice. Present study evaluated 39 varieties of Sri Lanka for grain amylose content and its stability over seasons. Twenty six traditional and 12 improved rice varieties and 1 introduced rice variety were evaluated over 2006 Yala and 200607 Maha seasons. Experiment in each season was conducted in a Randomized Complete Block Design at the Regional Rice Research and Development Center, Bombuwela. Amylose content was determined by standard iodine colorimetric method. Grain amylose content significantly varied from 23 to $31 \%$ among varieties. Irrespective of traditional or improved, all the varieties except Suduru Samba and Basmathi 370 (intermediate amylose contents: 20-24\%), had high amylose contents $(\geq 25 \%)$ in both seasons. In both traditional and improved varieties, varietal differences for stability of grain amylose content over seasons were found. Higher proportion of improved varieties showed stable amylose content over seasons than that of traditional varieties. Interestingly, both the varieties with intermediate amylose showed stability over seasons. Varieties with high and intermediate amylose contents that are stable over seasons are valuable germplasm in terms of grain amylose content. Therefore, such varieties can be used in rice grain quality improvement program in Sri Lanka.
\end{abstract}

Keywords: Grain amylose content, rice, stability over seasons, traditional and improved varieties, Sri Lanka

\section{INTRODUCTION}

Rice mainly consists of starch (Juliano, 2003) and there are two different types of storage starches namely amylose and amylopectin (Juliano, 1985; Juliano, 2003; Fitzgerald et al., 2009a; Chen et al., 2012). Amylose content of rice is considered as the most important predictor influencing the sensory quality of rice (Fitzgerald et al., 2009a). It is commonly used as an objective index for cooked rice texture (Webb, 1991; Asghar et al., 2012). Low amylose levels are associated with cohesive, tender, and glossy cooked rice (Juliano, 1971). Conversely, high levels of amylose cause rice to absorb more water and consequently expand comparatively more during cooking and the grains tend to cook dry, fluffy, and separate (Juliano, 1971; Fitzgerald et al., 2009a; Patindol et al., 2010).

Countries around the world have different preferences for rice with varying amylose contents (Juliano, 1985; Juliano, 2003; Calingacion et al., 2014). Consumer preference for rice around the world, when eaten an intact grain is largely dependent on a desire for its cooked texture to be either firm and non-sticky or soft and sticky (Chen et al., 2007). Amylose content is the major factor related to cooked rice texture (Fitzgerald et al., 2009b). Therefore,

\footnotetext{
Industrial Technology Institute (ITI), 363, Bauddhaloka Mawatha, Colombo 07, Sri Lanka.

2 Rice Research and Development Institute (RRDI), Batalagoda, Sri Lanka.

3 CIC Agribusiness Centre, Pelwehera, Dambulla, Sri Lanka.
} 
rice breeders invariably are concerned with and routinely select for desired amylose content in new lines (Fitzgerald et al., 2009b; Calingacion et al., 2014).

The grain amylose content can vary among varieties due to genetic and environmental factors (Chen et al., 2007; Chen et al., 2012). The environmental conditions such as the temperature and day length and genotype $x$ environment interaction also affect the amylose content of different varieties of rice (Lin et al., 2005). Several other studies have shown that the interaction between genotype and ambient temperature also has an effect on amylose content in rice grains (Nkori Kibanda and Luzi-kihupi, 2007; Patindol et al., 2015). Thus, amylose content varies over seasons in the same site of cultivation even with the same variety (Inatsu, 1979; Asaoka et al., 1984). Grain amylose content of rice is influenced by ambient temperature (Chen et al., 2007; Ahmed et al., 2015) and it decreases with the increasing environmental temperatures (Ahmed et al., 2015). Environmental temperature during seed development affects the amylose synthesis in rice with the $\mathrm{Wxb}$ allele. The level of the $\mathrm{Wx}$ protein increase in lower temperatures, resulting in higher amylose contents in mature seeds (Inatsu, 1979; Asaoka et al., 1984). Chen et al., (2007) reported that higher air temperature during grain development associated with a decrease in amylose content of rice varieties having low and intermediate amylose contents, but with an increase in rice varieties with high amylose content. Heritability that shows the proportion of genetic variability relative to total phenotypic variability for grain amylose content in rice has also been studied. Heritability values from low to high have been reported. Rafii et al., (2014) reported very low (31.74\%) while Nirmaladevi et al., (2015) reported very high $(93 \%)$ broad sense heritability estimates. Asfaliza et al., (2012) reported low broad sense $(45.45 \%)$ as well as narrow sense $(39.26 \%)$ heritability values.
Studies on how starch characteristics vary in response to seasonal differences and development of rice varieties with desirable amylose contents that do not change over seasons are important. The current trend of rice breeding research is also for the development of rice varieties having desirable grain quality traits with less sensitivity particularly to seasonal differences. Therefore, the objective of the present study was to evaluate the variety and variety $\times$ season interaction effects of the grain amylose content of rice using a set of rice genotypes in Sri Lanka.

\section{MATERIALS AND METHODS}

\section{Materials}

A total of twenty six traditional and twelve improved local rice varieties and one introduced 'Basmathi' rice variety were used in the study (Table 01).

\section{Experimental design}

The experiment was conducted at the Regional Rice Research and Development Center (RRRDC), Bombuwala, over 2006 Yala and 2006/07 Maha seasons. Rice varieties were planted in a Randomized Complete Block Design (RCBD) with two replications in each season. Plot size of the experiment was $1.9 \times$ $1.2 \mathrm{~m}$ and rice seedlings (18 days old) were transplanted in the experimental plots at a spacing of $15 \times 20 \mathrm{~cm}$ within and between rows with one plant per hill.

\section{Amylose Content}

Varieties were harvested at physiological maturity. Rice seeds were stored at $8^{\circ} \mathrm{C}$ prior to analysis of grain amylose. Rice seed samples were dehulled using a dehuller machine (Satake THU 35B, Japan) and stored in airtight containers at $8^{\circ} \mathrm{C}$ in a cold room. The milled rice grains were used for the determination of amylose content 
using the standard Iodine Colorimetric Method (Juliano, 1985). One $\mathrm{mL}$ of $95 \%$ ethanol and 9 $\mathrm{mL}$ of $1 \mathrm{~N}$ sodium hydroxide were added to 100 $\mathrm{mg}$ of flour sample. The sample was heated for $10 \mathrm{~min}$ in a boiling water bath to gelatinize the starch. Sample was allowed to cool and volume was made up to $100 \mathrm{~mL}$. Five milliliters of solution, $1 \mathrm{~mL}$ of $1 \mathrm{~N}$ acetic acid and $2 \mathrm{~mL}$ of $0.2 \%$ iodine solution were transferred to 100 $\mathrm{mL}$ volumetric flack and volume was made up to $100 \mathrm{~mL}$. Flask was shaken and allowed to stand for $20 \mathrm{~min}$ at $30{ }^{\circ} \mathrm{C}$. Absorbance was measured at $620 \mathrm{~nm}$ using a UV/visible spectrophotometer (GBC-911A, Scientific Equipment, Australia). Total amylose content was determined from a standard potato amylose curve (Potato, Sigma Type III). Analysis was performed in quadruplicate for each and every variety in each season. Based on the amylose content, rice varieties were then classified into low amylose (12-20\%), intermediate amylose (20-25\%) and high amylose (25-33\%) groups (Frei et al., 2003).

\section{Statistical Analysis}

Data on grain amylose content of 39 rice varieties were analyzed using the method proposed in Abeysiriwardena et al., (1991) using SAS statistical software. Deviation $\left(\mathrm{d}_{\mathrm{ijk}}\right)$ of the grain amylose content of each variety in each plot within a season from the season mean (plot deviation) was computed as follows;

$$
\mathrm{d}_{\mathrm{jjk}}=\mathrm{y}_{\mathrm{jjk}}-\overline{\mathrm{y}}_{\mathrm{j}}
$$

Where, $\mathrm{d}_{\mathrm{ijk}}$ is the deviation of the grain amylose content of the $\mathrm{i}^{\text {th }}$ variety in the $\mathrm{k}^{\text {th }}$ block in the $\mathrm{j}^{\text {th }}$ season from $\mathrm{j}^{\text {th }}$ seasonal mean (average over all varieties and blocks). Sum over variety deviations for each season was zero so that the effect of season became zero. The mean of variety deviations across seasons for each variety $\left(D_{i}\right)$ estimated the average effect of that variety across seasons and it was calculated as follows;

$$
D_{1}=\sum_{j=1}^{n} \bar{d}_{i j} / n
$$

Where, " $n$ " is the number of seasons.

Combined analysis of variance (ANOVA) over seasons on the plot deviations for amylose content was performed. When interaction effect of variety $\times$ season was found to be significant, it was further analyzed to derive stability parameters $\left(\mathrm{S}^{2}\right)$ one corresponding to each variety $\left(\mathrm{S}_{\mathrm{i}}{ }^{2}\right)$ as follows;

$$
S_{i}^{2}=\left[\sum_{j=1}^{n} d_{i j}^{2}-\frac{\left(\sum_{j=1}^{n} d_{i j}\right)^{2}}{n}\right] / q^{(n-1)}
$$

Each variety's $\mathrm{S}_{\mathrm{i}}^{2}$ could be tested against the pooled error by an " $F$ " test to see whether it was different from zero or significant. Nonsignificant $\mathrm{S}_{\mathrm{i}}^{2}$ of a variety indicates that the variety does not interact with the environment in an unpredictable manner so that the variety is stable over seasons with respect to the amylose content. Duncan New Multiple Range Test (DNMRT) was performed to separate variety means. Thus, this method provides the opportunity to select stable varieties over seasons at a desired content of amylose.

\section{RESULTS AND DISCUSSION}

The selected Sri Lankan traditional rice varieties are the ones that are still cultivated and available among farmers. Most of the improved Sri Lankan rice varieties used in the study are the most popular and widely grown and consumed varieties in the country. Yala is the season with comparatively higher rainfall starting from March and ending in August and Maha is the season with comparatively lower rainfall starting from September and ending in February of the following year in the Low Country Wet Zone of Sri Lanka. Maximum 
and minimum temperatures of Yala and Maha experimental seasons were $29.1-31.8{ }^{\circ} \mathrm{C}$ and $23.1-26.9^{\circ} \mathrm{C}$ and $29.5-31.7{ }^{\circ} \mathrm{C}$ and 22.1 $25.1^{\circ} \mathrm{C}$, respectively. Although Yala season is reported to have a higher ambient temperature than in Maha season only the minimum temperature in Yala was about $1^{\circ} \mathrm{C}$ more than that of Maha in the present study.

\section{Amylose content of rice varieties}

The results from the combined analysis of variance performed on plot deviations of grain amylose content from seasonal means indicated that both variety and the variety $x$ season interaction effects were highly significant. Hence, the mean deviation of the amylose content over seasons or the ' $\mathrm{D}$ ' value and the stability parameter $\left(\mathrm{S}^{2}\right)$ over seasons corresponding to each variety were estimated and tested against the pooled error. Variability of ' $D$ ' values exactly represents the variability of actual average amylose contents of varieties over seasons so that mean separation of ' $D$ ' values is as same as the mean separation of actual average amylose contents of varieties over seasons (Abeysiriwardena et al., 1991). Therefore, instead of reporting ' $D$ ' values, actual average mean amylose contents of varieties over seasons are reported with the same mean separation. Amylose content and its stability over seasons of 26 traditional and 12 improved rice varieties and one introduced 'Basmati' variety grown in 2006 Yala and 2006/07 Maha seasons in the LCWZ of Sri Lanka are presented in Table 01.

In the present study grouping of rice varieties was based on overall average amylose content of varieties and variety stability estimates in amylose content over seasons derived by analyzing the variety $\times$ season interaction effect.
All the rice varieties except Suduru Samba and Basmati 370 were high ( $>25 \%$ ) in grain amylose content. Amylose content of Suduru Samba and Basmati 370 was intermediate (20 - 25\%). Out of 25 high amylose traditional varieties, 17 recorded higher but only 8 recorded lower grain amylose content than the overall average amylose content across seasons (27.86\%), respectively. Similarly, out of 12 high amylose improved varieties, 6 recorded higher and 6 recorded lower grain amylose content than the overall average amylose content across seasons, respectively. Genetics play a major role in the amylose content of rice. The waxy gene, located in rice chromosome 6 , encodes the enzyme granule bound starch synthase (GBSS) which plays a key role in amylose synthesis (Smith et al., 1997; Chen et al., 2007). Jeng et al., (2003) and Nishi et al., (2001) reported that the activity of GBSS at the grain filling stage was positively correlated with the amylose content in rice grains. Two waxy gene alleles, Wxa and Wxb, have been associated with the contents of GBSS and amylose in rice endosperm. Rice strains with the $\mathrm{Wxb}$ allele contain $15-20 \%$ amylose in contrast to rice strains with the Wxa allele with $\geq 20-25 \%$ amylose content in the rice grain (Sano, 1984).

Out of 25 high amylose traditional varieties, only 11 were found to be stable over seasons. Similarly out of 12 high amylose improved varieties, only 7 were found to be stable over seasons. Thus, higher proportion of improved varieties (58\%) than that of traditional varieties (44\%) showed stable amylose content over seasons in the Low Country Wet Zone of Sri Lanka. Interestingly, both varieties, Suduru Samba and Basmathi 370, with intermediate amylose content were also found to be stable over seasons. 
Table 01: Grain amylose contents and their stability parameters $\left(\mathrm{S}^{2}\right)$ of 39 rice varieties grown in Maha and Yala seasons in the Low Country Wet Zone of Sri Lanka

\begin{tabular}{|c|c|c|c|c|}
\hline \multirow[b]{2}{*}{ Variety $^{\dagger}$} & \multirow[b]{2}{*}{ 2006/07 Maha } & \multicolumn{3}{|c|}{ Amylose content $\%$} \\
\hline & & 2006 Yala & Mean over seasons ${ }^{ \pm}$ & Stability parameter $\left(\mathrm{S}^{2}\right)$ \\
\hline Rathal & 29.27 & 30.05 & $29.66 \mathrm{a}$ & $0.689^{*}$ \\
\hline Murungakayan & 30.10 & 28.55 & $29.32 \mathrm{ab}$ & $2.25 * *$ \\
\hline Kahata Wee & 30.94 & 27.60 & $29.27 \mathrm{ab}$ & $10.824 * * *$ \\
\hline Kalu Heeneti & 29.15 & 29.20 & $29.18 \mathrm{abc}$ & 0.010 \\
\hline Dik Wee & 28.28 & 30.07 & $29.17 \mathrm{abc}$ & $3.386^{* *}$ \\
\hline Rath Suwandel & 29.10 & 29.20 & $29.16 \mathrm{abc}$ & 0.023 \\
\hline Hondarawala & 29.20 & 28.69 & $28.94 \mathrm{bcd}$ & 0.212 \\
\hline Sulai & 28.79 & 28.64 & $28.72 \mathrm{cde}$ & 0.009 \\
\hline KaluBala Wee & 29.03 & 28.23 & $28.63 \mathrm{def}$ & $0.562 *$ \\
\hline Madathawalu & 28.60 & 28.18 & $28.39 \mathrm{efg}$ & 0.130 \\
\hline Batapolal & 28.64 & 28.11 & $28.38 \mathrm{efg}$ & 0.235 \\
\hline Kottayar & 27.63 & 28.96 & $28.29 \mathrm{efg}$ & $1.904 * *$ \\
\hline Masuran & 27.82 & 28.60 & $28.21 \mathrm{efgh}$ & $0.681^{*}$ \\
\hline Gonabaru & 30.19 & 27.24 & 28.18fghi & $15.761 * * *$ \\
\hline Goda Heeneti & 27.31 & 29.01 & $28.16 \mathrm{fghi}$ & $3.028 * *$ \\
\hline Molligoda & 28.79 & 27.24 & 28.01ghij & $2.25 * *$ \\
\hline Herath Banda & 27.51 & 28.50 & 28.00ghij & $1.082^{*}$ \\
\hline Devaraddiri & 27.38 & 28.01 & 27.70hijk & $0.462 *$ \\
\hline Wannidahanala & 28.52 & 26.83 & $27.67 \mathrm{hijk}$ & $2.722 * *$ \\
\hline Pachaperumal & 27.65 & 27.65 & $27.65 \mathrm{ijkl}$ & 0.003 \\
\hline Dahanala & 27.14 & 27.99 & $27.57 \mathrm{jkl}$ & $0.801 *$ \\
\hline Beheth Heeneti & 28.11 & 26.78 & $27.44 \mathrm{kl}$ & $1.651 * *$ \\
\hline Sudu Heeneti & 27.53 & 27.17 & $27.35 \mathrm{kl}$ & 0.096 \\
\hline Kattamanjal & 26.22 & 28.43 & $27.32 \mathrm{kl}$ & $5.085 * *$ \\
\hline Rathu Heeneti & 26.59 & 26.42 & $26.50 \mathrm{~m}$ & 0.013 \\
\hline Suduru Samba & 24.70 & 24.21 & $24.45 p$ & 0.292 \\
\hline Bg 352 & 28.98 & 29.90 & $29.44 a b$ & $0.951^{*}$ \\
\hline $\mathrm{Bg} 359$ & 29.30 & 29.15 & $29.25 \mathrm{ab}$ & 0.021 \\
\hline At 354 & 28.23 & 29.95 & $29.10 \mathrm{bcd}$ & $3.133^{* *}$ \\
\hline Bw 267-3 & 28.28 & 29.08 & $28.68 \mathrm{cdef}$ & $0.7225^{*}$ \\
\hline At 353 & 28.47 & 27.63 & $28.05 \mathrm{ghij}$ & $0.632 *$ \\
\hline $\mathrm{Bg} 300$ & 28.26 & 27.82 & 28.04ghij & 0.148 \\
\hline Bg 379-2 & 27.77 & 27.60 & 27.69hijk & 0.014 \\
\hline Bw 361 & 27.46 & 27.22 & $27.34 \mathrm{kl}$ & 0.034 \\
\hline Bw 272-6b & 26.68 & 27.58 & 27.131 & $0.893 *$ \\
\hline $\mathrm{Bg} 360$ & 26.39 & 26.22 & $26.31 \mathrm{~m}$ & 0.014 \\
\hline At 306 & 25.40 & 25.76 & $25.58 \mathrm{~h}$ & 0.172 \\
\hline Bg 406 & 25.16 & 25.01 & $25.08 \mathrm{o}$ & 0.010 \\
\hline Basmati 370 & 23.44 & 23.34 & $23.39 p$ & 0.002 \\
\hline
\end{tabular}

†Varieties with names are traditional and varieties with numbers are improved except 'Basmathi 370' which is introduced ${ }^{ \pm}$Values with the same letter are not significantly different at 0.05 probability level

${ }^{*, * *, * * *}$ Significant at $0.05,0.01$ and 0.001 probability levels, respectively 
Rice with high amylose content is preferred in South Asia including Sri Lanka. Sri Lankans traditionally eat and tend to favor flaky, somewhat hard non cohesive rice. Thus, it is quite clear that high amylose rice as a breeding objective is justified. Brekenridge (1980) also reported that high grain amylose content close to $25 \%$ was taken as a breeding objective in the Sri Lanka rice improvement program in the past. Either traditional or improved, almost all the Sri Lankan rice varieties recorded high grain amylose contents. This is in agreement with Brekenridge (1980) who reported that all Sri Lankan rice, both traditional and improved belonged to the high amylose group with grain amylose contents ranging from 25 - 29\%. However, only some of the varieties included in the present study, including both traditional (Kalu Heeneti, Rath Suwandel, Hondarawala, Sulai, Madathawalu, Batapolal, Pachaperumal, Sudu Heeneti and Rathu Heeneti) and improved (Bg 359, Bg 300, Bg 379-2, Bw 361, Bg 360 or Keera Samba, Bg 406 and At 306), showed stability of grain amylose content over seasons in the LCWZ and those are valuable germplasm that can be used in rice improvement programs for high and stable grain amylose content over seasons.

Unfortunately, the variety $\mathrm{Bw}$ 272-6b which is high in grain $\mathrm{Fe}, \mathrm{Zn}$ and protein contents (unpublished data) and the variety Bw 267-3 which is reported to be tolerant to Fe toxicity (Bentota and Weerasinghe, 2005) were not stable in grain amylose content over seasons in the LCWZ of Sri Lanka. Among all traditional and improved varieties, two traditional varieties namely Kahata Wee and Gonabaru appeared highly unstable in grain amylose content over seasons. They have recorded higher amylose in Maha season than that of in Yala season and this difference cannot be attributed to temperature as Maha and Yala recorded almost the same temperature during the course of the study. However, this seasonal difference in grain amylose content may be attributed to day length (Lin et al., 2005) as day length in Maha season is shorter than that of Yala season and grain amylose content of these two traditional varieties may be sensitive to day length. In addition, identification of one traditional variety (Suduru Samba) and one introduced variety (Basmathi 370) having intermediate grain amylose content with stability over seasons is also immense importance as valuable germplasm.

\section{CONCLUSIONS}

Significant variation in grain amylose content ranging from high (30.07) to intermediate (23.34) among the selected Sri Lankan traditional and improved rice varieties was observed. Varietal differences for stability in grain amylose content over seasons in both traditional and improved varieties were also observed. Varieties with stable grain amylose contents over seasons can be utilized in rice variety improvement programs for grain quality improvement in the LCWZ of Sri Lanka.

\section{ACKNOWLEDGEMENTS}

The authors acknowledge the financial support granted by the Sri Lankan Treasury to ITI (10715/TG6).

\section{REFERENCES}

Asaoka, M., Okuno, K., Sugimoto, Y., Kawakami, J. and Fuwa, H. (1984). Effect of environmental temperature during development of rice plants on some properties of endosperm starch, Starch. 36:189-193 https:/doi.org/10.1002/star.19840360602 
Asfaliza, R., Rafii, M.Y., Saleh, G., Omar, O. and Puteh, A. (2012). Combining ability and heritability of selected rice varieties for grain quality traits. Australian Journal of Crop Science. 6(12): 1718-1723.

Asghar, S., Anjum, F.M., Amir, R.M. and Khan, M.A. (2012). Cooking and eating characteristics of rice (Oryza sativa L.) - A review, Pakistan Journal of Food Science. 22(3): 128-132.

Bentota, A.P. and Weerasinghe, B.G.D.S. (2005). Iron toxicity tolerance in some traditional rice varieties of Sri Lanka, Annals of the Sri Lanka Department of Agriculture, Department of Agriculture, Peradeniya, Sri Lanka. 7:337-340.

Brekenridge, C. (1980). Grain quality as a component of the rice varietal improvement program, Rice Symposium 80. Department of Agriculture, Peradeniya, Sri Lanka. pp. 259-282.

Calingacion, M., Laborte, A., Nelson, A., Resurreccion, A., Concepcion J.C., Daygon V.D. et al., (2014). Diversity of global rice markets and the science required for consumer-targeted rice breeding, PLoS One. 9(1):e85106. doi: 10.1371/journal.pone.0085106. https:/doi. org/10.1371/journal.pone.0085106

Chen, M.-H., Bergman, C., Pinson, S. and Fjellstrom, R. (2007). Waxy gene haplotypes: Associations with apparent amylose content and the effect by the environment in an international rice germplasm collection, Journal of Cereal Science. 47(3): 536-545. https:/doi.org/10.1016/j. jcs.2007.06.013

Chen, Y., Wang, M. and Ouwerkerk, P.B.F. (2012). Molecular and environmental factors determining grain quality in rice, Food and Energy Security. 1(2): 111-132. https:/doi. org/10.1002/fes3.11

Fitzgerald, M.A., Bergman, C.J., Resurreccion, A.P., Moller, J., Jimenez, R. et al., (2009b). Addressing the dilemmas of measuring amylose in rice, Cereal Chemistry. 86:492-498. https:/doi.org/10.1094/CCHEM-86-5-0492

Fitzgerald, M.A., McCouch, S.R. and Robert, D.H. (2009a). Not just a grain of rice: the quest for quality, Trends in Plant Science. 14(3): 133-139. https:/doi.org/10.1016/j.tplants.2008.12.004

Frei,M., Siddhuraju, P. and Becker, P.S.K. (2003). Studies on the in vitro starch digestibility and the glycemic index of six different indigenous rice cultivars from the Philippines, Food Chemistry.83: 395-402. https:/doi.org/10.1016/S0308-8146(03)00101-8

Inatsu, O. (1979). Improvement of the quality of rice grown in Hokkaido, Journal of Japanese Society Starch Science. 26: 191-197. https:/doi.org/10.5458/jag1972.26.191

Jeng, T.L., Tseng, T.H., Wang, C.S., Chen, C.L. and Sung, J.M. (2003). Starch biosynthezing enzymes in developing grains of rice cultivar Tainung 67 and its sodium azide -induced rice mutant, Field Crops Research. 84: 261-269. https:/doi.org/10.1016/S0378-4290(03)00094-7

Juliano B.O. (2003). Production and utilization. In: Rice Chemistry and Quality. Island Publishing House, Inc. Sta. Mesa P.O. Box 406, Manila, Philippines. pp. 1-17.

Juliano, B.O. (1971). A simplified assay for milled-rice amylose, Cereal Science Today. 16: 334340. 
Juliano, B.O. (1985). Rice Chemistry and Technology (B.O. Juliano, Ed.). American Association of Cereal Chemists, Inc, St. Paul, Minnesota, USA.

Lin, J., Shi, C., Wu, M. and Wu, J. (2005). Analysis of genetic effects for cooking quality traits of japonica rice across environments, Plant Science. 168: 1501-1506. https:/doi.org/10.1016/j. plantsci.2005.02.018

Nirmaladevi, G., Padmavathi, G., Kota, S. and Babu, V.R. (2015). Genetic variability, heritability and correlation coefficients of grain quality characters in rice (Oryza sativa L.). SABRAO Journal of Breeding and Genetics. 47(4): 424-433.

Nishi, A., Nakamura, Y., Tanaka, N. and Satoh, H. (2001). Biochemistry and genetic analysis of the effects of amylose-extender mutation in rice endosperm, Plant Physiology. 127: 459-472. https:/doi.org/10.1104/pp.010127

Nkori Kibanda, J.M. and Luzi-kihupi, A. (2007). Influence of genetic and genotype x environment interaction on quality of rice grain, African Crop Science Journal. 15(4): 173 - 182.

Patindol, J.A., Siebenmorgen, T. J. and Wang, Y-J. (2015). Impact of environmental factors on rice starch structure: A review, Starch/Stärke. 67: 42-54. https:/doi.org/10.1002/star.201400174

Patindol, J., Gu, X. and Wang, Y-J. (2010). Chemometric analysis of cooked rice texture in relation to starch fine structure and leaching characteristics, Starch - Stärke. 62: 188-197. https:/doi. org/10.1002/star.200900181

Rafii, M.Y., Zakiah, M.Z., Asfaliza, R., Iffah Haifaa, M.D., Latif, M.A. and Malek, M.A. (2014). Grain quality performance and heritability estimation in selected F1 rice genotypes. Sains Malaysiana. 43(1): 1-7.

Sano, Y. (1984). Differential regulation of waxy gene expression in rice endosperm, Theoretical and Applied Genetics. 68: 467-473. https:/doi.org/10.1007/BF00254822

Smith, A.M., Denyer, K. and Martin, C. (1997).The synthesis of the starch granule, Annual Review of Plant Physiology and Plant Molecular Biology. 48: 67-87. https:/doi.org/10.1146/annurev. arplant.48.1.67

Webb, B.D. (1991). Rice quality and grade. In: Rice (Eds. B.S. Luh). Van Nostrand Reinhold, New York. pp. 89-119. https:/doi.org/10.1007/978-1-4899-3754-4_16 